\title{
THE EFFECTS OF A VIDEO GAME ON STUDENT PERFORMANCE IN THE' KNOWLEDGE TEST IN THE DISCIPLINE "PROFESSIONAL PRACTICE AND ETHICS IN PHYSIOTHERAPY" FROM THE UNIVERSITY OF BRASILIA
}

\author{
EFEITO DO VIDEOGAME NO DESEMPENHO DE TESTE DE CONHECIMENTOS DE \\ ALUNOS DA DISCIPLINA "EXERCÍCIO PROFISSIONAL E DEONTOLOGIA EM \\ FISIOTERAPIA" DA UNIVERSIDADE DE BRASÍLIA
}

EFECTO DE LO VIDEOJUEGO SOBRE EL RENDIMIENTO DE LA PRUEBA DE
CONOCIMIENTO A LOS ESTUDIANTES DE LA DISCIPLINA " PRÁCTICA
PROFESIONAL Y ÉTICA EN FISIOTERAPIA " DE LA UNIVERSIDAD DE BRASILIA

Ana Clara Bonini Rocha ${ }^{1}$ Jorge Luís Barreto Pereira ${ }^{2}$ Caio Felipe Teixeira Soares ${ }^{3}$

Priscilla Barbosa ${ }^{4}$

Amanda Cindy da Silva ${ }^{5}$ André Marques de Moraes ${ }^{6}$ Wagner Rodrigues Martins ${ }^{7}$

\section{ABSTRACT}

The current study had the objective of evaluate the long term effect of the educational video game (EVG) in the specific knowledge test (SKT) performance, opinion of satisfaction with the discipline (SAT) and learning perception of the subject matter (LP) of a graduation discipline in the Physiotherapy course of the University of Brasilia (UNB). This study is a randomized clinical trial with two groups: Experimental Group (EG): Attending instead presential classes with extra time for EVG. Control Group (CG): only attending regular timeclasses. The classes occurred once a week with the presence of both groups. Students allocated in EG needed to access the

\footnotetext{
${ }^{1}$ Doutora em Ciências do Movimento Humano - Universidade Federal do Rio Grande do Sul (UFGRS) - Porto Alegre, RS - Brasil. Professora Associada II - Universidade de Brasília - Campus Ceilândia (FCE/UnB) - Brasília, DF - Brasil. Email:anaclara@unb.br

${ }^{2}$ Coordenador do Laboratório de ITÁLIA (Inovações Tecnológicas para Experimentar Ambientes) Centro de Apoio ao Desenvolvimento Tecnológico (CDT/UnB) - Brasília, DF - Brasil. Email:jorge.pereira@cdt.unb.br ${ }^{3}$ Graduado em Fisioterapia - Universidade de Brasília - Campus Ceilândia (FCE/UnB) - Brasília, DF - Brasil. Email:cfts @hotmail.com

${ }^{4}$ Graduado em Fisioterapia - Universidade de Brasília - Campus Ceilândia (FCE/UnB) - Brasília, DF - Brasil. Email:barbosa.priscilla@gmail.com

${ }^{5}$ Graduado em Fisioterapia - Universidade de Brasília - Campus Ceilândia (FCE/UnB) - Brasília, DF -Brasil. Email:amandacindys@gmail.com

${ }^{6}$ Graduado em Fisioterapia - Universidade de Brasília - Campus Ceilândia (FCE/UnB) - Brasília, DF - Brasil. Email:andremarquesm94@gmail.com

${ }^{7}$ Doutor em Ciências da Saúde - Universidade de Brasília - Campus Ceilândia (FCE/UnB) - Brasília, DF - Brasil. Professor adjunto no Curso de Fisioterapia - Universidade de Brasília - Campus Ceilândia (FCE/UnB) - Brasília, DF - Brasil. Email:wagnermartins@unb.br
}

Submetido em: 15/05/2016 - Aceito em: 10/10/2016
(C) ETD-Educação Temática Digital
Campinas, SP
v.19
n. 2
p. $570-581$
abr./jun. 2017 
EVG platform once a week. After 17 weeks, the assessment tools were applied for the dependent variables: (I) SKT, (2) SAT and (3) LP. The Student t test was used to compare the SKT means between groups and for the absolute and relative frequencies, were used to report SAT and LP scales. The data was analyzed with statistical significance of $5 \%$. The sample consisted of a total of 71 students $(22,83[ \pm 3,35]$ years old), including 62 females $(87,3 \%)$ and 9 males $(12,7 \%)$ individuals. There was a significant statistical difference between EG and CG in SKT ( $p=0.006)$, with the EG having higher means than CG. Regarding the secondary endpoints EG had $100 \%$ answers in categories 4 and 5, while the GC also showed responses in category 3 . The study results points that de EVG was able to improve the performance in the SKT. The SAT results may indicate that the use of the EVG can increase the satisfaction with the discipline and the learning perception of the subject matter.

KEYWORDS: Teaching, Satisfaction, Learning Perception, Videogame, Physiotherapy, Ethics

\section{RESUMO}

O presente estudo teve como objetivo avaliar o efeito de longo prazo do vídeo game educacional (VGE) no desempenho em teste de conhecimentos específicos (TCE), opinião de satisfação com a disciplina (SAT) e percepção de aprendizagem dos conteúdos (PA) de uma disciplina da graduação em fisioterapia da Universidade de Brasília. Trata-se de um ensaio clínico randomizado com dois grupos: Grupo Experimental (GE): aulas presencias e uso semanal do VGE extraclasse; Grupo Controle (GC): apenas aulas presenciais. As aulas presenciais ocorreram uma vez por semana com ambos os grupos presentes. Os alunos do GE precisaram acessar a plataforma do VGE uma vez por semana. Após 17 semanas foram aplicados os instrumentos de avaliação das variáveis dependentes: (I) TCE; (2) SAT; (3) PA. Utilizamos o teste t Student para comparar as médias do TCE entre os grupos e frequências absolutas e relativas para reportar as escalas SAT e PA. Os dados foram analisados com nível de significância 5\%. A amostra foi composta por um total de 71 alunos $(22,83[ \pm 3,35]$ anos de idade), sendo 62 indivíduos do sexo feminino $(87,3 \%)$ e 09 do sexo masculinos $(12,7 \%)$. Houve diferença estatisticamente significante entre GE e GC no TCE ( $p=0.006)$, apresentando o GE maior média que o GC. Em relação aos desfechos secundários O GE apresentou 100\% das respostas nas categorias 4 e 5, enquanto, o GC também apresentou respostas na categoria 3. Os resultados da pesquisa indicaram que o VGE foi capaz de melhorar o desempenho em teste de conhecimentos específicos. Os resultados de opinião parecem indicar que a utilização do VGE pode aumentar a satisfação com a disciplina e a percepção de aprendizados do conteúdo.

PALAVRAS-CHAVE: Ensino. Satisfação. Percepção de Aprendizagem. Videogame. Fisioterapia. Ética.

\section{RESUMEN}

El estudio tuvo como objetivo evaluar el efecto a largo plazo del videojuego educativo (VJE) en la realización de la prueba de conocimientos específicos (TCE), opinión de la satisfacción con la disciplina (SAT) y la percepción de los contenidos de aprendizaje (PCA) del curso de graduación en fisioterapia en la Universidad de Brasilia. Se trata de un ensayo clínico aleatorizado con dos grupos: grupo experimental (GE): clases presenciales y uso semanal de VJE extra clase; Grupo control (GC): sólo las clases presenciales. Las clases ocurrieran una vez por semana con los dos grupos presentes. Los estudiantes del grupo GE necesitaban acesar a la plataforma VJE una vez a la semana. Después de 17 semanas, se aplicaron los instrumentos de evaluación de las variables dependientes: TCE (I); (2) SAT; (3) PCA. Se utilizó el Test t de Student para comparar las medias del TCE entre los grupos y las frecuencias absolutas y relativas, para informar las escalas del SAT y PCA. Los datos se analizaron con nivel de significación de 5\%. La muestra estuvo constituida por un total de 71 estudiantes $(22,83[ \pm 3,35]$ años), 62 mujeres $(87,3 \%)$ y 09 hombres $(12,7 \%)$. No hubo diferencias significativas entre GE y GC en el TCE $(p=0,006)$, con GE teniendo medias superiores a GC. Mientras los criterios de valoración secundarios GE tuvo $100 \%$ de las respuestas en las categorías 4 y 5, mientras que el GC también mostró respuestas en la categoría 3. Los resultados indicaron que el VJE fue capaz de mejorar el rendimiento en la prueba de conocimientos específicos. Los resultados de laopiniones parecen indicar que la utilización del VJE puede aumentar la satisfacción con la disciplina y la percepción de los contenidos de aprendizaje.

PALABRAS CLAVE: Enseñanza.Satisfacción.Percepción de aprendizaje.Videojuego.Fisioterapia.Ética.

$$
\text { (C) ETD-Educação Temática Digital Campinas, SP v.19 n.2 } \quad \text { p. 570-581 abr./jun. } 2017
$$




\section{INTRODUCTION}

Education aims to develop brain functions, i.e., transform the way the brain works through learning (Lee \& Jones, p. 13-44, 2008). Learning promotes behavioral changes in response to acquisition, consolidation and storage of certain information in the memory (Mourão, Melo, p. 309-314, 2011). In practice, the cognitive organization required to decipher and understand information generates memory and learning (Ramos, 2013; Weimtraub, Hawlistscheck, 2011, Rece, Pizner, 2002).

Several educational and neurobiological theories explain learning and, based on these theories, teachers can evaluate how they are teaching (Tokuhama-Ezpinoza, 2008). Nowadays, to succeed in learning, new ways of teaching using new theories and technologies have been stimulated (Tokuhama-Espinoza, 2010). In this sense, dissemination on the internet in educational spaces, inside and outside the classroom and, following the same trend, the use of video games, is noteworthy (Alves, 2005).

The new forms of content presentation in the virtual world directly interfere in the student expectations of school (Oliveira, 2010) and directly affect the educational demands of the teacher, not only with regard to content, but to the emotional demands related to the learning process. If the student feels satisfied with the teaching method, they can better understand their evolution, motivating them to learn more. Thus, satisfaction presupposes a relationship with motivation. To feel motivated an individual wants and is able to maintain attention, concentration and effort during the time necessary to achieve the intended objective (Boruchovitch, Bzuneck, 2010; Kahneman, 1999).

Educators have long recognized the potential of gaming software to teach. The $1980 \mathrm{~s}$ was a classic example of demand to obtain computers in the classroom to practice educational games such as Oregon Trail, created to help teach geography. Currently, it is known that these visual games can be excellent teaching tools (Gentile, Gentile, 2008). Video games potentially stimulate the nervous system through visual stimuli, captured by observing the screen, developing the player's attention and encouraging the acquisition of short-term memory. Thus the student may have greater capacity to absorb and concentrate on content (Lameira, Gawryszewski, Pereira, 2006).

Recognizing the importance of using new technology to facilitate a change in the behavior of university students, the Technological Innovation Laboratory for Experience Environments (ITAE) of the Technological Development Support Center (CDT) at the

\section{(c) ETD-Educação Temática Digital Campinas, SP v.19 n.2 p.570-581 abr./jun. 2017}


University of Brasilia (UnB) and the UnB physiotherapy program developed an educational video game on an electronic platform calibrated with specific content from the Professional Practice and Ethics in Physiotherapy discipline (EPDF) of the Physiotherapy program at UnB. Considering this context, the objective of this study was to evaluate the long-term effects of the extracurricular use of an educational video game (EVG) on performance in the specific knowledge test, perception of learning the content covered during the semester and satisfaction with the discipline in question. The studied population was young adults students in higher education.

\section{METHODS}

Type of Study: this is a randomized clinical trial with two parallel groups.

Sample: Students enrolled on the Physiotherapy program in the compulsory subject of EPDF (8th semester curriculum flow) participated in the study; the students were required to be registered on the course. The present study did not adopt any exclusion criterion for the selection of participants. The following were adopted as discontinuity criteria: (1) frequency of attendance of less than $75 \%$ in the 17 meetings; (2) not accessing the EVG platform at least once a week; (3) accessing the platform once a week but not playing until the end of the task.

The students participating in the study were randomly assigned through a simple draw into: (1) Experimental Group (EG) with extra-curricular access to the EVG; (2) Control Group (CG) without access to the extra-curricular resource.

The research project and the informed consent (FICT) were submitted and approved by the Research Ethics Committee of the Faculty of Health Sciences at UNB, opinion no.: 1.079.867. All students understood the research objectives and consented to participation in the study by signing the FICT. There was no case of students being excluded from the sample.

\section{INSTRUMENTS}

Educational Video game: access to the EVG was through the ITAE platform on the $\mathrm{CDT} /$ UnB website. The platform is a modern virtual environment used for training through online immersion games that can be molded according to requirements, with easy to change contents, interacting with lights, sounds, movements and characters.

(C) ETD-Educação Temática Digital Campinas, SP $\quad$ v.19 $\quad$ n.2 $\quad$ p.570-581 abr./jun. 2017 
The EVG created and used for this study was the quiz type (answers to questions). In the game room it was possible to create and configure a room considering the following aspects: 1 - type of game; 2 - individual, double or team game; 3 - response time to questions; 4 - play time; 5 - images used; 6 - auxiliary resources (texts, videos, etc.); 7 questions in order or randomized. The game room was available until a new room was built with new questions. The questions had four formats: multiple choice, single choice, true or false and association between columns. By responding to questions, the players earned resources to enter the game (points). The more resources they earned, the more moves they could make. To finish the game, each participant was required to correctly answer all the questions; anyone who did not answer the question within the time limit or got the answer wrong was out of the game, after which they were required to re-access the room and the wrong question through random distribution.

\section{PROCEDURES}

In the final 20 minutes of the first day of classes (in both semesters), students were invited to participate in the study as volunteers. All the procedures relating to the allocation of the groups, calibration of the video game and signature of the FICT were developed blindly in relation to the teacher responsible for the EPDT discipline. During the course the teacher taught all weekly classroom content as set out in the syllabus planning of the course.

The students in the GE group were instructed to enter the platform at least once a week with the use of a personal password and complete all the tasks required in the game. The platform remained available to access during the opening time in each game room, so the students had free access to the platform during this period. The educational video game contained two types of question gaming options: (1) insignia puzzle of Physiotherapy displayed on the screen (individual mode). The number of pieces of the figure increased, the easiest puzzles were completed with the correct answer; (2) naval battle on the battlefield in the case of double games (versus mode). The student earned ammunition to attack by correctly answering the question, and moved to the next stage of the quiz.

Control of the players on the electronic platform was performed by the researcher who monitored the number of times each student accessed the platform. To calibrate the educational game with the course content, weekly, this same researcher was present in all classes. Thus, new rooms in the video game, including new knowledge covered in the

\section{(C) ETD-Educação Temática Digital Campinas, SP v.19 n.2 p.570-581 abr./jun. 2017}


classroom, were available the day after the meeting. From this point on, the previous game room was no longer available. Weekly support was offered to the students inthe EG group via e-mail and a workshop at the Information Laboratory of the FCE.

Both groups attended the class together and at the end of the $17^{\text {th }}$ week, assessment instruments were applied for the dependent variables of the study.

Dependent study variables: the primary outcome of the study was the specific knowledge test (SKT), that is, the final test to verify the learning of the content taught in the discipline, such as moral and technical aspects related to the professional practice of physiotherapy and specific ethics. The SKT was developed containing 80 questions including single and multiple choices, relationships between columns and true or false options $(0.125$ points for each question). The students were allowed between 30 and 90 minutes to perform the test. Incomplete or partially correct answers were considered completely incorrect.

The secondary outcomes of the study were: (1) satisfaction with the discipline (SAT), evaluated by means of a scale in the Likert format. The scale contained the following response options: 1 - not at all satisfied; 2 - somewhat satisfied; 3 - neither satisfied nor dissatisfied; 4 - satisfied; 5 - very satisfied; (2) the perception of the learning content (LP), also evaluated by means of a scale in a Likert format. The scale contained the following response options: 1 - learned nothing; 2 - learned little; 3 - neither learned nor not learned; 4 - learned; 5 - learned a lot.

\section{STATISTICAL ANALYSIS}

The characterization of the subjects is presented as mean \pm SD. The Shapiro-Wilk test was used to test the normality of the data of the primary outcome (continuous variable). Considering these data presented normal distribution, the Student $t$ test was used to compare groups. The secondary outcomes (ordinal categorical variables) were presented as absolute and relative frequencies. Data were analyzed using GraphPad Prism software (version 6.0) with a significance level of $5 \%$ for the hypothesis test.

\section{RESULTS}

The sample was composed of a total of 71 students (22.83 [ \pm 3.35 ] years), 62 females $(87.3 \%)$ and 09 males (12.7\%). Table 1 presents the profile separated by group and primary
(c) ETD-Educação Temática Digital
Campinas, SP v.19
n.2
p. $570-58$
abr./jun. 2017 
DOI: https://doi.org/10.20396/etd.v19i2.8645950

TABLE 1 - Characterization data of the sample and dependent variables of the study

\begin{tabular}{|c|c|c|c|c|c|c|}
\hline \multirow[b]{2}{*}{ Groups } & \multirow{2}{*}{$\begin{array}{c}\text { Age } \\
\text { (years) }\end{array}$} & \multicolumn{2}{|c|}{ Sex } & \multirow{2}{*}{$\begin{array}{c}\text { SKT* }^{*} \\
\text { (points) }\end{array}$} & \multicolumn{2}{|c|}{ Scales } \\
\hline & & Feminine & Masculine & & $\begin{array}{c}\text { SAT } \\
\text { (1 to 5) }\end{array}$ & $\begin{array}{c}\text { LP } \\
\text { (1 to 5) }\end{array}$ \\
\hline$E G=32$ & $\begin{array}{c}22.46 \\
( \pm 2.21)\end{array}$ & $\begin{array}{c}30 \\
(93.8 \%)\end{array}$ & 02 (6.2\%) & $9.07( \pm 0.60)$ & $\begin{aligned} 4 & =19 \% \\
5 & =81 \%\end{aligned}$ & $\begin{array}{l}4=37 \% \\
5=63 \%\end{array}$ \\
\hline$C G=39$ & $\begin{array}{c}22.66 \\
( \pm 2.46)\end{array}$ & $\begin{array}{c}32 \\
(82.1 \%)\end{array}$ & 07 (17.9\%) & $8.58( \pm 0.64)$ & $\begin{array}{l}3=15 \% \\
4=39 \% \\
5=46 \%\end{array}$ & $\begin{array}{l}3=10 \% \\
4=59 \% \\
5=31 \%\end{array}$ \\
\hline
\end{tabular}

*Difference between groups $(p=0.006)$; SKT = specific knowledge test; SAT = satisfaction with the discipline (categories 1 to 5); LP = perception of content learning (categories 1 to 5)

and secondary results. Each student accessed a total of 8 games rooms with an average frequency of $1.43(S D=0.54)$ times through the ITAE platform.

There were significant differences between the EG and CG groups in the SKT ( $p=$ 0.006), with the EG presenting a higher average than the CG. Regarding the secondary outcomes, the EG group, both for the SAT and LP, presented responses only in categories 4 (19\% [SAT], 37\% [LP]) and 5 (81\% [SAT], 63\% [LP]). In contrast, the CG also presented responses in category 3 (15\% [SAT], 10\% [PA]). In the SAT, both the EG and CG groups presented a higher percentage of responses in category 5 (very satisfied). Regarding the LP, the EG presented a higher percentage of responses in category 5 (learned a lot), while the CG presented a higher percentage of responses in category 4 (learned). The answers in category 5 , the highest values in the Likert scales, were $35 \%$ higher in the SAT and $32 \%$ higher in the LP for the EG compared to the CG.

\section{DISCUSSION}

The present study aimed to evaluate the long-term effects of the extracurricular use of an educational video game (EVG) on performance in the specific knowledge test (SKT), the perception of learning (LP) of the content during the semester and also the satisfaction (SAT) of the course. Our results has shown that EVG was able to improve performance in the SKT, in general, it was instrumental in achieving a higher percentage of response in category 5 in the EG group.

For the EG, the EVG formed part of the teaching plan of the EPDF course, and the students played with the ethical and moral rules of their own discipline. Due to the

\section{(c) ETD-Educação Temática Digital Campinas, SP v.19 $\quad$ n.2 $\quad$ p. 570-581 abr./jun. 2017}


requirement of additional cognitive effort, the acquisition of information may have been potentiated. The EG students were attentive to the content for longer through challenging activities that involved questions, scores and game battles (naval). It is likely that might have activated and evoked knowledge already acquired in in the classroom. Reconsolidation through memory reinforcement and storage are direct effects of selective attention (Mishrae, 2012; Figueiredo, Sbissa, 2013). In the study of Oei et al. (2013), 5 groups of novice participants in video games, each with their mobile played for one hour per day, five days per week for four weeks ( 20 hours). The conclusion of this study reinforces our primary finding since according to these authors the formation of specific cognitive skills results from playing the games that share the requirements commonly underpinning the desired skills. Thus, cognitive development related to the game could be attributed to transfers made. Therefore, the GE group may actually have benefited from the EVG to give better performance in the SKT. The same authors confirmed that the aforementioned transfer to a cognitive task is more likely if a common underlying ability is highly practiced in a video game during the same cognitive task (Oei, Patterson 2015).

Regarding the SAT and LP, the results demonstrated a slight tendency to a higher percentage of satisfaction with the course and perception of content learning in the EG group. The EG presented $100 \%$ of answers in categories 4 and 5, while the CG also presented responses in category 3. Responses in category 3 mean "neither satisfied nor dissatisfied" (SAT; 15\%) and "neither learned nor not learned" (LP, 10\%). Thus, adding together the categories 4 and 5, the CG obtained $87 \%$ (SAT) and 90\% (LP). Furthermore, when analyzing the responses in category 5 , the EG presented percentages $35 \%$ higher (SAT) and $32 \%$ higher (LP) than the CG. Even though we were able to highlight a trend using the statistical analysis employed, it is not possible to say whether there were statistically significant differences between the groups for the secondary variables.

Classic studies in the area of psychology regarding with motivation aspects point to the fact that, in the educational context where games influence performance measures, the motivation construct becomes further expanded (Hughes, Redfield, Martray, 1989). Motivated by the score and/or winning or losing the games, students increasingly want to try to win the game and move on to the next step (Boruchovitch, Bzuneck, 2010). Motivation associated with the pleasure of playing evokes emotion, which potentiates memory consolidation and storage (Garcia, 2015). Thus, motivation may have been an attribute that created absolute and percentage differences between the groups regarding the SAT and LP. Based on these opinions, it is assumed that the students in the EG group were motivated when they responded only in categories 4 and 5 . They were satisfied because they trusted that they were memorizing knowledge through the EVG. Finally, the
(c) ETD-Educação Temática Digital
Campinas, SP
v.19
n.2
p. $570-581$
abr./jun. 2017 
CG may have resented the fact that they were deprived access to the ITAE; however, they were satisfied with the discipline.

Despite the popularity of video games among students and even among educators, three pillars are considered fundamental for success in the use of games in the teaching process: prepared educators; appropriate structure and planning and; quality and variability of games available (Wang, 2009). Regarding the games used in the present study, the ITAE enabled the intersection of entertainment, cognition and technology, achieving and offering opportunities for the exercise and development of cognitive skills that were important in the teaching-learning process. The ability to access the ITAE from any computer, at convenient times and with colleagues in double games, probably relieved the students of pressure situations common in a full classroom, providing a familiar atmosphere, emotional security and the absence of tension or danger (Wojciechowski, Vosgerau, 2010). In this sense, educational games facilitate recreational access to information and the exchange of information between students and teachers in low risk situations and low pressure environments. For Kashimoto (1998), playful behavior offers opportunities to experiment with behaviors that, in normal situations, would often never be attempted due to fear of error or punishment.

The main limitation of the present study was the fact that the participants knew to which group their colleagues belonged. Thus, for example, a student in the control group may have been frustrated by the fact that a well-known classmate had access to the EVG while they did not. The present study also cannot affirm that the consolidated memory was stored or that the contents of the EPDF would be available in the future. The subjective nature of human experience is perhaps another limitation of the study. Among possibilities such as texts, images, video lessons and dynamics of the classroom, the EVG is one more supporting tool for the learning process. Despite this, we observed that the addition of this instrument allowed for better performance in the SKT and the opinion scales. Despite this, we emphasize that in all educational and interpersonal relations and circumstantial situations, both in the classroom and out of it, emotional and psychological bias exists.

\section{CONCLUSION}

The results of this study indicate that the EVG was able to improve performance in the specific knowledge test. The opinion results seem to indicate that the use of the EVG can increase satisfaction with the discipline and perception of the learning content.

(C) ETD-Educação Temática Digital Campinas, SP v.19 n.2 $\quad$ p. 570-581 abr./jun. 2017 
DOI: https://doi.org/10.20396/etd.v19i2.8645950

\section{REFERENCES}

ALVES, Luciana.; CARVALHO, Alysson Massote. Videogame: é do bem ou do mal? Como orientar pais. Maringá: Psicologia em Estudo, v. 16, n.2, p. 251-258, abr./jun. 2011.

AMABILE, Teresa M. et al.The work preference inventory:assesing intrinsic and extrinsic motivational orientations. Journal of Personality and Social Psychology, v. 66, n. 5, p. 950967, May 1994.

ANDERSON, Craig A. An update on the effects of playing violent video games.JournalofAdolescence: Elsevier, v. 27, n. 1, p. 113-122,2004

BORUCHOVITCH, Evely; BZUNECK, José Aloyseo. A motivação do aluno: contribuições da psicologia contemporânea. São Paulo: Vozes, 2010.

FELDMAN Jerome; MCPHEE, Doug. The Science of learning and the art of theaching. New York/EUA: Thomson Delmar Learning, 2008.

FERNANDES, Elisângela. Aula expositiva: o professor no centro das atenções. Local da publicação: Revista nova escola, 2011. Disponível em:

http://revistaescola.abril.com.br/gestao-escolar/aula-expositiva-professor-centro-atencoes645903.shtml. Acesso em: 12/09/2014.

FIGUEIREDO, Odair; SBISSA, Pedro Paulo Mendes. Efeito dos jogos eletrônicos sobre atenção seletiva. Ciências\&Cognição, v. 18, n. 2, p. 129-135, 2013.

GARCIA, Cristiane Sousa; FACCHINETTI, Livia Dumont. PROFISIO Programa de Atualização em Fisioterapia Neurofuncional.Porto Alegre: ArtmedPanamericana, 2015.

GENTILE, Douglas.The Multiple Dimensions of Video Game Effects. Child Development Perspectives, v. 5, n. 2, p. 75-81, 2011

GENTILE, Douglas; GENTILE, J. Ronald. Violent video games as exemplary teachers: A conceptual analysis. Journal of Youth and Adolescence, v. 9, p. 127-141, 2008

HUGHES, Kervin R. et al. The children's academic motivation inventory: a research note on psychometric properties. Measurement and Evaluation in Counseling and Development, $v$. 22, p. 137-142, 1989.

KAHNEMAN, Daniel. Objective happiness.In:DIENER, Edward; SCHWARZ, Norbert; KAHNEMAN, Daniel. Well-being:thefoundationsofhedonic psychology. NewYork/EUA: Russell Sage Foundation, p. 3-25, 1999.
(C) ETD-Educação Temática Digital
Campinas, SP v.19
n.2
p. $570-581$
abr./jun. 2017 
KISHIMOTO, TizukoMorchida. O brincar e suas teorias. São Paulo: Pioneira, 1998.

LAMEIRA, AallanPablo; GAWRYSZEWSKI, Luiz de Gonzaga; PEREIRA JR, Antônio. Neurônios espelho. Psicologia USP, v. 17, n. 4, p. 123-133, 2006.

LEE, Ilchi; JONES, C. Jessie. Full a Bloom: A Brain Education Guide for Successful Aging. Best Life Media; Sedona, AZ. Ciências\&Cognição, v. 18, n. 1, p. 13-44, 2008.

MARTINELLI, Selma de C.; BARTHOLOMEU, Daniel. Escala de Motivação Acadêmica: uma medida de motivação extrínseca e intrínseca. AvaliaçãoPsicológica v. 6, n. 1, p. 21-31, 2007.

MERIANS, Alma S. et al.Virtual Reality-Augmented Rehabilitation for Patients Following Stroke. Physycal Therapy, v. 82, n. 9, p. 898-915, sep. 2002.

MISHRA, Jyoti; BAVELIER, Daphne; GAZZALEY, Adam.How to Assess Gaming-Induced Benefits on Attention and Working Memory Assess Gaming-Induced Benefits on Attention and Working Memory. Games Health J., v. 1, n. 3, p. 192-198, jun. 2012.

MOTA, Ronaldo. Olhando para o futuro: visões da educação brasileira para os próximos 10 anos. Revista Tecnológica Educacional, v. 39, n. 191, p. 26-38, 2010.

MOURÃO-JÚNIOR, Carlos Alberto; MELO, Luciene Bandeira Rodrigues. Integração de três conceitos: Função Executiva, Memória de Trabalho e Aprendizado. Psicologia: Teoria e Pesquisa, v. 27, n. 3, p. 309-314, 2011.

OEI, Adam C.; PATTERSON, Michael D. Enhancing perceptual and attentional skills requires common demands between the action video games and transfer tasks. Frontiers in psychology, v. 6, feb. 2015.

OEI, Adam C.; PATTERSON, Michael D. Enhancing cognition with video games: a multiple game training study.PLoSOne, v. 8, n. 3, 2013.

OLIVEIRA, Eloiza da Silva. Ação docente na educação a distância: competências do professor invisível. Tecnologia educacional, v. 39, n. 190, p. 15-26, 2010.

PEREIRA, Alice Theresinha Cybis; SCHMITT, Valdenise; DIAS, MariaRegina Alvares Correia. AVA - Ambientes Virtuais de Aprendizagem.In: PEREIRA, Alice Teresinha. AVA - Ambientes virtuais de aprendizagem em diferentes contextos. Rio de Janeiro/RS: Editora Ciência Moderna Ltda. 2007.

\section{(C) ETD-Educação Temática Digital Campinas, SP v.19 n.2 p.570-581 abr./jun. 2017}


PEREIRA, Jorge Luís Barreto; BONINI-ROCHA, Ana Clara. Prática de informática na educação: Ambiente de experiência ITAE com alunos da Universidade de Brasília. In: Anais do II Congresso Brasileiro de Informática na Educação. 2013, p. 316-325.

PYLRO Simone Chabudee, ROSSETTI Claudia Broetto. Atividades lúdicas, gênero e vida adulta. Psico-USF, v. 10, n. 1, p. 77-86, 2005.

RAMOS, Daniela Karine. Jogos cognitivos eletrônicos na escola: exercício e aprimoramento dos aspectos cognitivos. Seminário Jogos Eletrônicos, Educação e Comunicação. In: Anais do IX Seminário Jogos Eletrônicos, Educação e Comunicação, 2013. Salvador: UNEB.

SANTAELLA, Lucia. Games e comunidades virtuais. Texto apresentado na Exposição Hiper relações Eletro-digitais. Porto Alegre-RS. Maio/Set. 2004.. Disponível em: <http://csgames.incubadora.fapesp.br/portal/publica/comu/>. Acesso em: 15/06/2014.

TEIXEIRA, Núbia PolianeCardoso; ARAUJO, Alberto Einstein Pereira de. Informática e educação: uma reflexão sobre novas metodologias. RevistaCompartilhandoSaberes, v. 1, n. 1, 30-41, 2009.

TOKUHAMA-ESPINOSA, Tracey Noel. (2008). The scientifically substantiated art of teaching: a study in the development of standards in the new academic field of neuroeducation (Mind, brain and education science). 2008. 600 p. Tese (Doutorado em Educação) CapellaUniversity, New York.

TOKUHAMA-ESPINOSA, Tracey Noel. The new science of teaching and learning. Using the best of mind, brain, and education science in the classroom. New York: TeachersCollege Press, 2010.

WANG, Wanderley. $\mathbf{O}$ aprendizado através de jogos para computador: por uma escola mais divertida e eficiente. 2009. Disponível na Web:

<http://www.educacaoetecnologia.org.br/?p=6098>. Acesso em: 10/05/2012.

WEINTRAUB, Miriam; HAWLITSCHECK, Philippe, JOÃO, Sílvia Maria Amado. Jogo educacional sobre avaliação em fisioterapia: uma nova abordagem acadêmica. Fisioterapia e Pesquisa, v. 18, n. 3, 280-6, 2011.

WOJCIECHOWSKI, Taís; VOSGERAU, Dilmeire. A utilização da internet nas escolas municipais de Curitiba. Revista Tecnologia Educacional, p. 39:15-34, 2010.

'Revisão gramatical do texto sob a responsabilidade dos autores

(C) ETD-Educação Temática Digital Campinas, SP v.19 n.2 $\quad$ p.570-581 abr./jun. 2017 